\title{
Evaluation of commercial utility of the developed knitted fabrics
}

Received: 28.08.2018; Revised: 09.04.2019; Accepted: 18.04.2019

See end of the paper for authors' affiliations Shikha Bajaj

Department of Apparel and Textile Science, College of Home Science, Punjab Agricultural University, Ludhiana (Punjab) India

Email : shikhabajaj26@ gmail.com
ABSTRACT : Knitted are elastic, porous fabrics and can be constructed faster and at less production cost compared to woven fabrics. These are characterised by low weight of fabric, comfort of wearing and little to no aftercare. In the present study, blended knitted fabrics developed in two different yarn counts were assessed on the basis of several factors of evaluation including production feasibility, production cost, visual impact, handfeel and saleability. An interview schedule was employed to study the opinions of respondents having expertise in knitted fabric construction, machinery handling and their judgment for developed knitted fabrics was recorded. Findings revealed that blended knitted fabrics wers highly production feasible. Parameters like visual impact, handfeel, fabric performance for clothing construction and saleability scored positive opinions as well.

KEY WORDS: Commercial, Fabrics, Feasibility, Knitting

- HOW TO CITE THIS PAPER : Bajaj, Shikha and Bains, Sandeep (2019). Evaluation of commercial utility of the developed knitted fabrics. Asian J. Home Sci., 14 (1) : 45-50, DOI: 10.15740/HAS/AJHS/ 14.1/45-50. Copyright@ 2019: Hind Agri-Horticultural Society. 